Article

\title{
Catalytic Wet Peroxide Oxidation of Cylindrospermopsin over Magnetite in a Continuous Fixed-Bed Reactor
}

\author{
Macarena Munoz ${ }^{1, *}$, David Ortiz ${ }^{1, *}$, Julia Nieto-Sandoval ${ }^{1}$, Samuel Cirés ${ }^{2}{ }^{\circledR}$, \\ Zahara M. de Pedro ${ }^{1}$, Antonio Quesada ${ }^{2}$ D and Jose A. Casas ${ }^{1}$ \\ 1 Departamento de Ingeniería Química, Universidad Autónoma de Madrid, Ctra. Colmenar, km. 15, \\ 28049 Madrid, Spain; julia.nieto-sandoval@uam.es (J.N.-S.); zahara.martinez@uam.es (Z.M.d.P.); \\ jose.casas@uam.es (J.A.C.) \\ 2 Departamento de Biología, Universidad Autónoma de Madrid, Ctra. Colmenar, km. 15, \\ 28049 Madrid, Spain; samuel.cires@uam.es (S.C.); antonio.quesada@uam.es (A.Q.) \\ * Correspondence: macarena.munnoz@uam.es (M.M.); david.ortiz@uam.es (D.O.); \\ Tel.: +34-91-497-3991 (M.M.)
}

Received: 20 October 2020; Accepted: 26 October 2020; Published: 29 October 2020

\begin{abstract}
The development of cost-efficient and environmentally friendly technologies for the removal of cyanotoxins from water is crucial, given the increasingly frequent appearance of toxic cyanobacterial blooms. In this work, the application of catalytic wet peroxide oxidation (CWPO) promoted by natural magnetite for the removal of the highly toxic cyanotoxin cylindrospermopsin (CYN) has been investigated. A fixed-bed reactor packed with magnetite powder and granules was used to treat a continuous flow of CYN-bearing water. Experiments were carried out under ambient conditions and circumneutral $\mathrm{pH}\left(\mathrm{pH}_{0}=5\right)$. The effect of the main variables of the process, viz. magnetite load (8-14 g), feed flow rate $\left(0.1-0.25 \mathrm{~mL} \mathrm{~min}^{-1}\right), \mathrm{H}_{2} \mathrm{O}_{2}$ dose $\left(0.5-8 \mathrm{mg} \mathrm{L}^{-1}\right)$ and initial CYN concentration (25-100 $\left.\mu \mathrm{g} \mathrm{L}^{-1}\right)$, were systematically analyzed. CYN conversion values and kinetic constants were calculated to evaluate the feasibility of the catalytic system. The process was highly effective in the removal of the cyanotoxin, achieving up to $80 \% \mathrm{CYN}$ conversion under optimized conditions (flow rate $=0.2 \mathrm{~mL} \mathrm{~min}^{-1},\left[\mathrm{H}_{2} \mathrm{O}_{2}\right]_{0}=5 \mathrm{mg} \mathrm{L}^{-1}, \mathrm{~W}_{\mathrm{Fe} 3 \mathrm{O} 4}=14 \mathrm{~g}, \mathrm{pH}_{0}=5, \mathrm{~T}=25^{\circ} \mathrm{C}$ ). It also showed reasonable activity ( $~ 55 \%$ CYN conversion) in two real samples (pond and river water). The decay on CYN conversion in these cases was mainly due to the scavenging of hydroxyl radicals by the co-existing species present in the matrices. Remarkably, the catalytic system showed high stability with limited iron leaching (the iron leached at the end of the experiments represented less than $0.2 \mathrm{wt}$ \% of the catalyst's initial iron content) in all cases. Its stability was further confirmed in a long-term continuous experiment (60 h time on stream). Furthermore, the magnetite granules at the top layer of the packed bed avoided the loss of magnetite powder from the reactor, confirming the suitability of the system for continuous long-term application.
\end{abstract}

Keywords: cyanotoxin; cylindrospermopsin; CWPO; magnetite; fixed-bed reactor

\section{Introduction}

The occurrence of cyanobacterial blooms has unabatedly increased in the past decades and nowadays represents one of the most challenging environmental issues worldwide [1]. Eutrophication and perhaps climate change are the main reasons behind this phenomenon of significant consequences, not only for the ecosystem sustainability but also for human health [2,3]. In addition to imparting taste, odor and color problems in water, cyanobacterial blooms can generate toxic secondary metabolites. These compounds, known as cyanotoxins, show diverse physical and chemical properties and exhibit 
different degrees of toxicity and a variety of health effects, from skin rashes to liver failure or respiratory arrest [4]. Accordingly, they pose a high risk to surface waters intended for recreational uses, irrigation and very especially drinking water.

Similar to other kind of organic pollutants such as pesticides, pharmaceuticals or personal care products, cyanotoxins are characterized by high persistency and may pass through the different steps of conventional drinking water treatment plants (DWTPs) [5]. Hence, the development of innovative treatment processes that ensure the complete removal of cyanotoxins and their derivatives is crucial. Advanced oxidation processes (AOPs) appear to be promising candidates for such goals, as they have proved to be highly effective in the elimination of most cyanotoxin classes [6,7]. Briefly, AOPs can be defined as oxidation methods based on the action of highly reactive species, mainly hydroxyl radicals. These non-selective and highly reactive species allow the removal of most organic pollutants from water in short reaction times [8].

In a recent work, a comprehensive overview of the application of AOPs for cyanotoxin removal considering the cost-effectiveness, technical feasibility and environmental character of such technologies was performed [9]. Fenton-based technologies were favorably compared with photocatalysis and ozone-based AOPs in terms of kinetics and operating costs. In particular, heterogeneous Fenton oxidation, also known as catalytic wet peroxide oxidation (CWPO), promoted by iron minerals was highlighted as a promising field of research. In our previous contribution [7], the $\mathrm{Fe}_{3} \mathrm{O}_{4}-\mathrm{R} 400 / \mathrm{H}_{2} \mathrm{O}_{2}$ catalytic system was shown to be highly effective for the removal of a representative group of cyanotoxins with a major impact on drinking water (microcystins (MC-LR, MC-RR), cylindrospermopsin (CYN), anatoxin- $a$ (ATX) and saxitoxin (STX)). Its feasibility was demonstrated even in the presence of natural organic matter and inorganic ions and was further confirmed in real surface water. Nevertheless, experiments were performed inbatch, which poses an important shortcoming for continuous application. In this sense, the development of packed reactors that allow the stable long-term operation of the system would represent an important step forward.

In this work, the feasibility of a fixed-bed reactor packed with a magnetite powder catalyst for the removal of cyanotoxins under continuous operation has been investigated. The cytotoxin CYN has been selected as target pollutant, given its broad distribution worldwide in tropical, subtropical and even temperate areas; its high stability in water regardless of heat, light and $\mathrm{pH}$ conditions; its remarkable release into the environment by a large number of cyanobacteria at significantly high extracellular concentrations and its exceptionally broad range of toxic effects including cytotoxicity, genotoxicity and carcinogenicity, among others [6,10-12]. Oxidation runs were performed under ambient conditions and circumneutral $\mathrm{pH}\left(\mathrm{pH}_{0}=5\right)$. The impact of the main variables of the system, viz. magnetite load, feed flow rate, $\mathrm{H}_{2} \mathrm{O}_{2}$ dose and initial $\mathrm{CYN}$ concentration, were systematically investigated. The stability of the reaction system was also analyzed in a long-term continuous experiment. As a proof of concept, the versatility of the process was finally evaluated using two representative environmental samples (pond and river water) as aqueous matrices.

\section{Results and Discussion}

\subsection{Operating Conditions Study}

As explained in Section 3.3, the reactor was packed with catalyst powder $\left(\mathrm{Fe}_{3} \mathrm{O}_{4}, 0.2 \mu \mathrm{m}\right)$ between two layers of magnetite granules (bottom layer: $2.5 \mathrm{~g}, 250-500 \mu \mathrm{m}$; top layer: $6 \mathrm{~g}, 500-1000 \mu \mathrm{m}$ ). The bed porosity $(\varepsilon)$ of the catalyst layer was 0.8 . The oxidation runs were carried out in up-flow current.

Blank experiments were preliminarily performed in order to evaluate the possible contribution to CYN's disappearance by degradation through a non-catalytic reaction with $\mathrm{H}_{2} \mathrm{O}_{2}$ or by adsorption on the magnetite bed. The possible oxidation of $\mathrm{CYN}$ by $\mathrm{H}_{2} \mathrm{O}_{2}$ in the absence of magnetite was discarded, since cyanotoxin conversion was below $5 \%$ after $6 \mathrm{~h}$ of reaction time. Along the same lines, CYN adsorption onto the magnetite's surface was negligible in the experiments carried out without $\mathrm{H}_{2} \mathrm{O}_{2}$. It must be also noted that the $\mathrm{Fe}_{3} \mathrm{O}_{4}$ granules used to pack the powder catalyst were 
not active under the operating conditions tested in this work, due to their significantly lower exposed surface area.

The effect of the catalyst bed load on the removal of CYN can be seen in Figure 1. The stripped area in this figure represents the time required to reach the steady state. As can be seen, CYN conversion (calculated by Equation (1)) increased from $\sim 20 \%$ to $~ 40 \%$ with an increasing amount of catalyst from $8 \mathrm{~g}$ to $14 \mathrm{~g}$. At the same time, the apparent pseudo-first order rate constant (calculated by Equation (2)), which included the catalyst and $\mathrm{H}_{2} \mathrm{O}_{2}$ concentrations, also increased from $5.58 \times 10^{-3}$ to $8.03 \times 10^{-3} \mathrm{~mL} \mathrm{~g}_{\mathrm{cat}^{-1}} \mathrm{~min}^{-1}$, as shown in Figure 2. It must be noted that in both cases, the removal of CYN remained unchanged during the time on stream, confirming the high stability of the catalyst. In fact, iron leaching was below $0.15 \mathrm{mg} \mathrm{L}^{-1}$ throughout the whole experiment, which represents a loss of iron from the catalyst below $0.2 \mathrm{wt} . \%$.

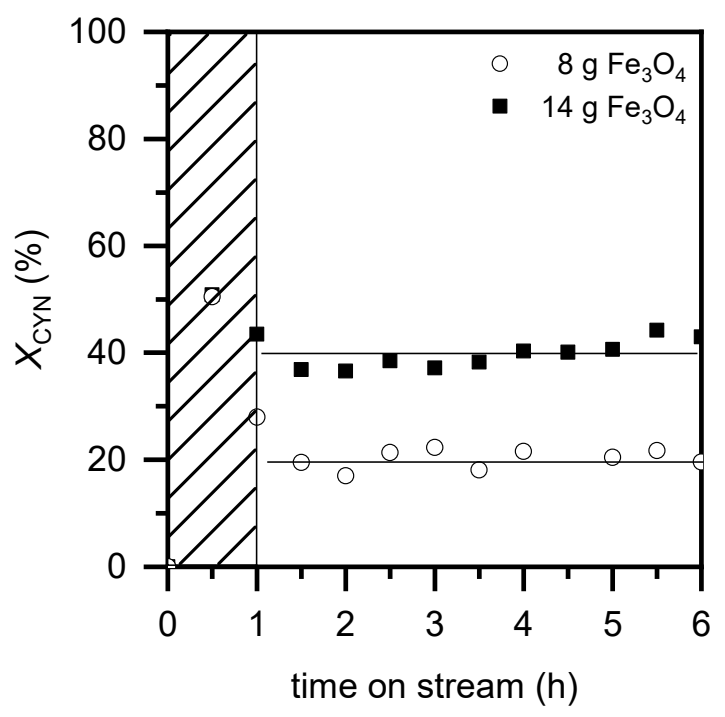

Figure 1. Effect of the catalytic bed load on the removal of cylindrospermopsin (CYN) upon catalytic wet peroxide oxidation (CWPO) (flow rate $=0.2 \mathrm{~mL} \mathrm{~min}^{-1}$, [CYN $]_{0}=25 \mu \mathrm{g} \mathrm{L}-1,\left[\mathrm{H}_{2} \mathrm{O}_{2}\right]_{0}=2 \mathrm{mg} \mathrm{L}^{-1}$, $\left.\mathrm{pH}_{0}=5, \mathrm{~T}=25^{\circ} \mathrm{C}\right)$.

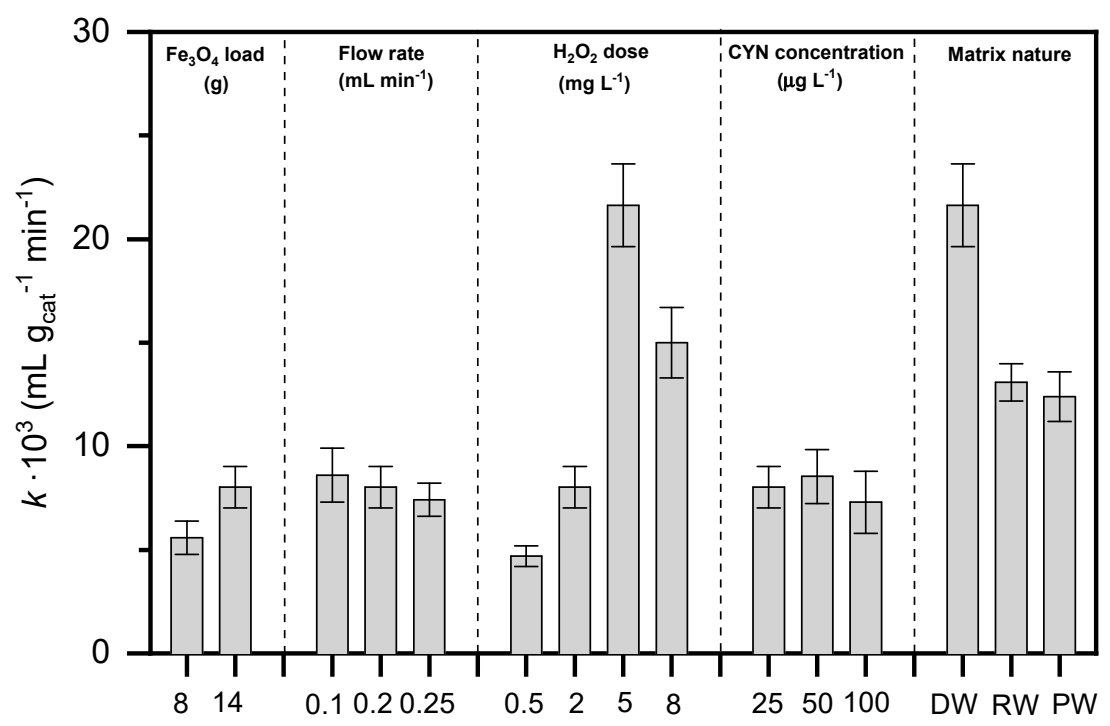

Figure 2. Apparent pseudo-first order kinetic constants obtained in the CWPO of CYN at different operating conditions (standard conditions: flow rate $=0.2 \mathrm{~mL} \mathrm{~min}{ }^{-1},[C Y N]_{0}=25 \mu \mathrm{g} \mathrm{L}{ }^{-1}$, $\left.\left[\mathrm{H}_{2} \mathrm{O}_{2}\right]_{0}=2 \mathrm{mg} \mathrm{L}^{-1}, \mathrm{~W}_{\mathrm{Fe} 3 \mathrm{O} 4}=14 \mathrm{~g}, \mathrm{pH}_{0}=5 ; \mathrm{T}=25^{\circ} \mathrm{C}\right)$. The abbreviations $\mathrm{DW}, \mathrm{RW}$ and $\mathrm{PW}$ stand for deionized water, river water and pond water, respectively. 
The impact of the feed flow rate of the CYN solution was investigated within the range of 0.1 to $0.25 \mathrm{~mL} \mathrm{~min}^{-1}$ using a catalyst bed load of $14 \mathrm{~g}$. The obtained results are depicted in Figure 3 . CYN conversion clearly decreased with an increasing feed flow rate as a consequence of the shorter space of time. Nevertheless, as can be seen in Figure 2, the kinetic constant remained almost unchanged. These results confirm that the system was not affected by diffusion limitations under the operating conditions tested.

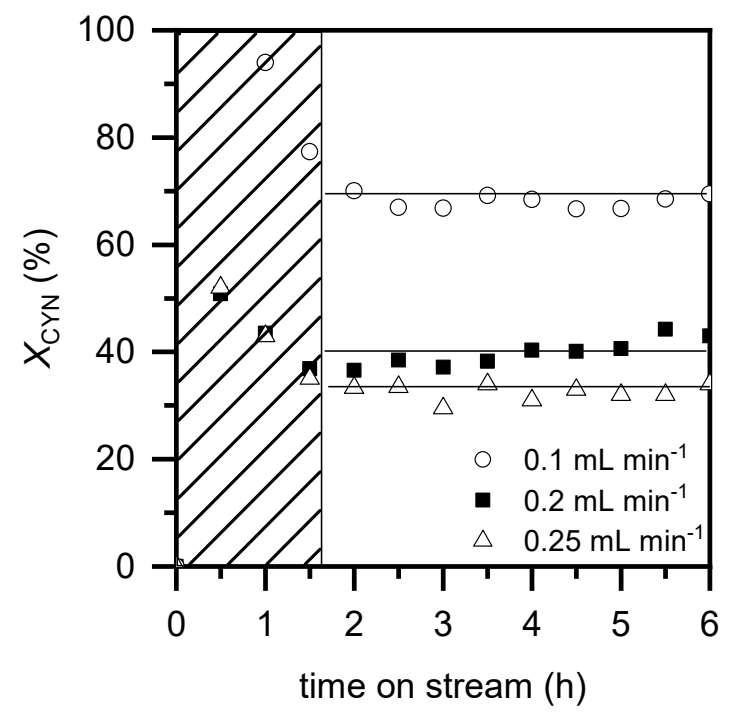

Figure 3. Effect of the feed flow rate on the removal of CYN upon CWPO $\left([\mathrm{CYN}]_{0}=25 \mu \mathrm{g} \mathrm{L}^{-1}\right.$, $\left.\left[\mathrm{H}_{2} \mathrm{O}_{2}\right]_{0}=2 \mathrm{mg} \mathrm{L}^{-1}, \mathrm{~W}_{\mathrm{Fe} 3 \mathrm{O} 4}=14 \mathrm{~g}, \mathrm{pH}_{0}=5, \mathrm{~T}=25^{\circ} \mathrm{C}\right)$.

The consumption of $\mathrm{H}_{2} \mathrm{O}_{2}$ is commonly identified as the main cost of Fenton-like processes [13-15]. Consequently, its dose must be carefully optimized in the treatment of a given raw water. The effect of $\mathrm{H}_{2} \mathrm{O}_{2}$ concentration on the removal of CYN within the 0.5 to $8 \mathrm{mg} \mathrm{L}^{-1}$ range is depicted in Figure 4 . As can be seen, CYN conversion increased with the $\mathrm{H}_{2} \mathrm{O}_{2}$ dose up to $5 \mathrm{mg} \mathrm{L}^{-1}$, where CYN conversion was around $80 \%$. Nevertheless, a further increase of the $\mathrm{H}_{2} \mathrm{O}_{2}$ concentration $\left(8 \mathrm{mg} \mathrm{L}^{-1}\right)$ led to a decrease of the cyanotoxin removal yield. In this run, where $\mathrm{H}_{2} \mathrm{O}_{2}$ concentration was in clear excess, the oxidant itself could compete with CYN for the available active sites at the magnetite's surface. Furthermore, it could also act as an HO- and HOO- scavenger, leading to termination reactions between both radicals and producing non-reactive molecular oxygen [16]. In agreement with these results, the apparent pseudo-first order kinetic rate constants also showed the same trend, reaching the highest value at $5 \mathrm{mg} \mathrm{L}^{-1} \mathrm{H}_{2} \mathrm{O}_{2}$. (Figure 2). Regarding the stability of the catalytic bed, it must be noted that Fe leaching did not increase remarkably with $\mathrm{H}_{2} \mathrm{O}_{2}$ concentration. In this sense, the concentration of dissolved iron was $0.2 \mathrm{mg} \mathrm{L}^{-1}$ at the most throughout the whole experiment under the different conditions tested.

The development of cyanobacterial blooms is a seasonal phenomenon, mainly influenced by the water temperature but also by the availability of nutrients [17]. On the other hand, it must be noted that the bloom itself is a successional process that includes growth, maintenance and decay stages $[18,19]$. Accordingly, notable fluctuations in cyanotoxin concentration are expected in the drinking water sources affected by cyanobacterial blooms. In this context, it is crucial to evaluate the impact of the initial concentration of cyanotoxins on the efficiency of the CWPO process. For this purpose, water with different initial CYN concentrations of 25,50 and $100 \mu \mathrm{g} \mathrm{L}-1$ were fed into the reactor. Figure 5 shows that changes in the initial concentration of the cyanotoxin did not affect its removal yield. From a kinetic point of view, these results demonstrate that CYN oxidation can be well described by a pseudo-first order kinetic equation. In fact, as can be seen in Figure 2, the apparent pseudo-first order kinetic constants were not affected by the initial concentration of CYN. As has been previously explained, the final CYN conversion could be modified by adjusting the appropriate dose of 
$\mathrm{H}_{2} \mathrm{O}_{2}$ to the inlet cyanotoxin-bearing water. From an operational point of view, these results confirm that the same installation would be suitable for the treatment of water polluted with the cyanotoxin throughout the bloom event.

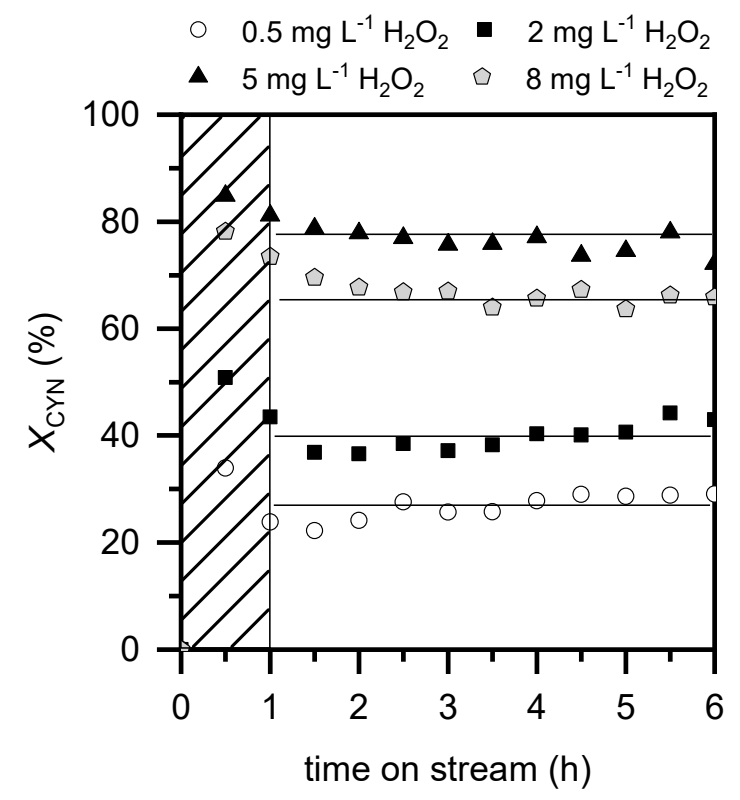

Figure 4. Effect of $\mathrm{H}_{2} \mathrm{O}_{2}$ dose on the removal of CYN upon CWPO (flow rate $=0.2 \mathrm{~mL} \mathrm{~min}^{-1}$, $\left.[\mathrm{CYN}]_{0}=25 \mu \mathrm{g} \mathrm{L}-1, \mathrm{~W}_{\mathrm{Fe} 3 \mathrm{O} 4}=14 \mathrm{~g}, \mathrm{pH}_{0}=5, \mathrm{~T}=25^{\circ} \mathrm{C}\right)$.

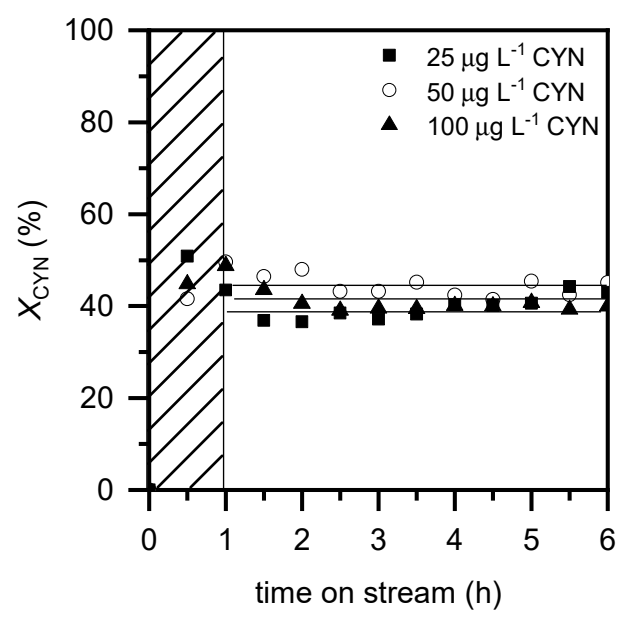

Figure 5. Effect of the initial concentration of CYN on its removal upon CWPO (flow rate $=0.2 \mathrm{~mL} \mathrm{~min}^{-1}$, $\left.\left[\mathrm{H}_{2} \mathrm{O}_{2}\right]_{0}=2 \mathrm{mg} \mathrm{L}^{-1}, \mathrm{~W}_{\mathrm{Fe} 3 \mathrm{O}}=14 \mathrm{~g}, \mathrm{pH}_{0}=5, \mathrm{~T}=25^{\circ} \mathrm{C}\right)$.

\subsection{Long-Term Stability}

To get further insights about the catalyst's stability, a long-term continuous experiment was carried out. The results obtained are depicted in Figure 6. As can be seen, the magnetite catalytic bed showed high stability, without any loss of activity observed at $60 \mathrm{~h}$ of time on stream. In accordance with these results, the concentration of dissolved iron was almost negligible throughout the long-term continuous experiment $\left(0.1-0.15 \mathrm{mg} \mathrm{L}^{-1}\right)$. The total iron leached after $60 \mathrm{~h}$ of time on stream represented less than $0.2 \mathrm{wt} . \%$ of the magnetite Fe content. The presence of carbonaceous deposits on the surface of the used catalyst was discarded, since its carbon content was below $0.1 \mathrm{wt} . \%$. At the same time, the specific surface area and magnetic properties of the solid remained unchanged. These results are in good agreement with previous work on organic pollutants other than $\mathrm{CYN}$, where it has been 
demonstrated that magnetite exhibits high stability in the CWPO of diluted organic pollutant solutions under ambient conditions [20].

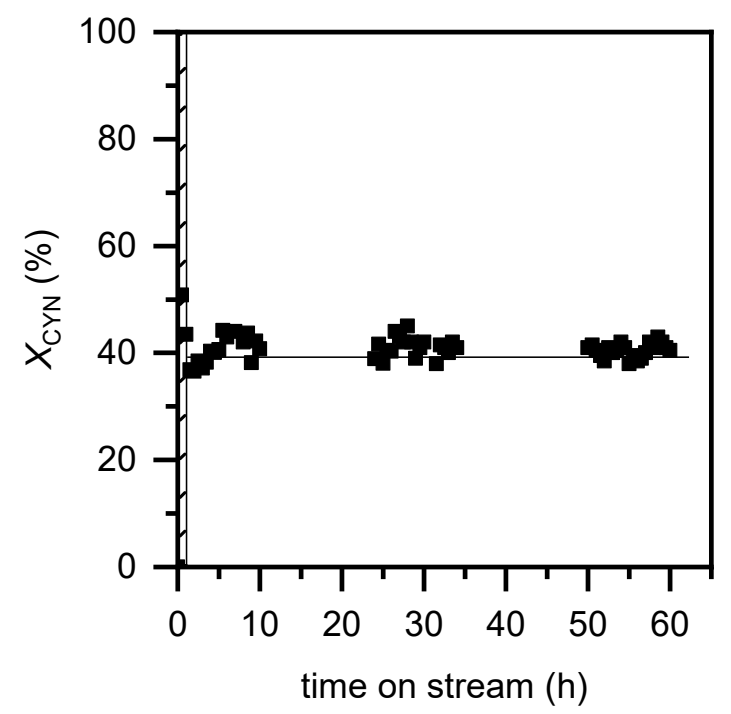

Figure 6. Long-term performance of the catalyst upon CWPO of CYN (flow rate $=0.2 \mathrm{~mL} \mathrm{~min}^{-1}$, $\left.[\mathrm{CYN}]_{0}=25 \mu \mathrm{g} \mathrm{L}^{-1},\left[\mathrm{H}_{2} \mathrm{O}_{2}\right]_{0}=2 \mathrm{mg} \mathrm{L}^{-1}, \mathrm{~W}_{\mathrm{Fe} 3 \mathrm{O} 4}=14 \mathrm{~g}, \mathrm{pH}_{0}=5, \mathrm{~T}=25^{\circ} \mathrm{C}\right)$.

\subsection{Operation in Real Water Matrices}

To learn more about the potential application of the CWPO process, the catalytic fixed-bed reactor was finally tested using different real water matrices fortified with CYN at $25 \mu \mathrm{g} \mathrm{L}{ }^{-1}$. River and pond water (RW and PW, respectively) were investigated as representative environmental samples. Their main characteristics are summarized in Table 1. Both samples showed a neutral $\mathrm{pH}$ value. Nevertheless, important differences were found regarding the content of organic matter and the conductivity values. Consistent with its stagnant conditions, the pond water showed almost two-fold the organic content of the flowing surface water. At the same time, the inorganic carbon content and conductivity value were also remarkably higher.

Table 1. Representative analysis of the real water matrices tested in this work.

\begin{tabular}{ccc}
\hline Parameter & River Water & Pond Water \\
\hline $\mathrm{pH}$ & 7.0 & 6.9 \\
$\mathrm{TOC}\left(\mathrm{mg} \mathrm{L}^{-1}\right)$ & 2.7 & 4.5 \\
$\mathrm{IC}\left(\mathrm{mg} \mathrm{L}^{-1}\right)$ & 14.9 & 47.2 \\
Conductivity $\left(\mathrm{mS} \mathrm{cm}^{-1}\right)$ & 200 & 497 \\
\hline
\end{tabular}

The evolution of CYN removal upon CWPO in the different water matrices tested is depicted in Figure 7. These experiments were performed with a $\mathrm{H}_{2} \mathrm{O}_{2}$ dose of $5 \mathrm{mg} \mathrm{L}^{-1}$. As can be seen, the degradation of CYN was clearly affected by the water matrix composition. The process was less effective in the real aqueous matrices compared with deionized water. In this sense, the cyanotoxin conversion decreased from $\sim 80 \%$ to values around $55 \%$. Similarly, the apparent pseudo-first order kinetic constant also decreased (Figure 2). These results can mainly be explained by the scavenging of hydroxyl radicals by inorganic species, like carbonate/bicarbonate, and by the consumption of radicals by the organic matter. Another possible reason could be competition by the co-existing species present in the real matrices for the active sites of the catalyst. Nevertheless, the specific surface area of magnetite remained unchanged after the treatment and the presence of carbonaceous deposits in the used catalysts was almost negligible $(<0.1 \mathrm{wt} . \%)$. In any case, it must be taken into account that the concentration of organic carbon in the real water matrices was up to two orders of magnitude higher 
than the concentration of the cyanotoxin. Therefore, it can be confirmed that the catalytic system showed extremely high selectivity towards CYN removal in the real water samples. Remarkably, the catalyst did not show any sign of deactivation throughout the $6 \mathrm{~h}$ of time on stream with any of the real water matrices tested.

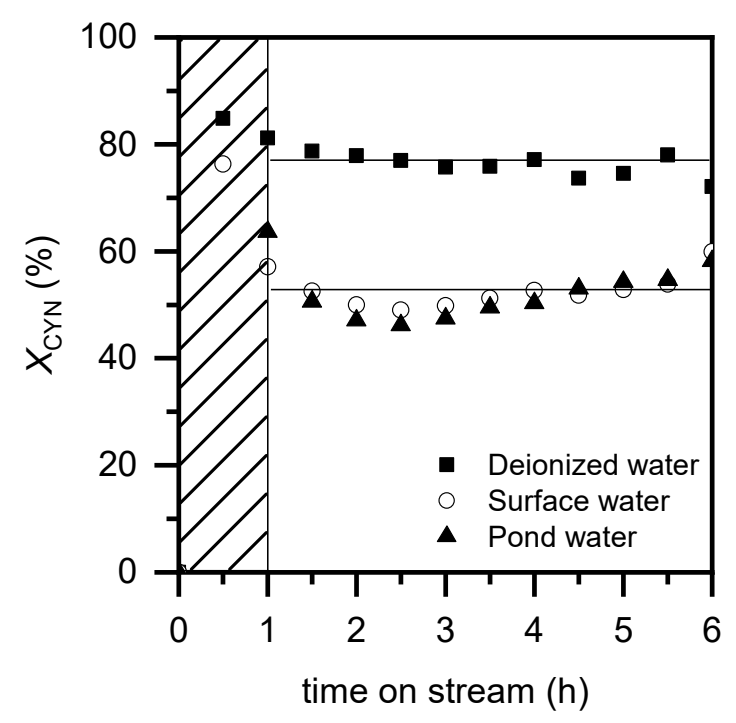

Figure 7. Impact of the water matrix nature on the removal of $\mathrm{CYN}$ upon $\mathrm{CWPO}$ (flow rate $=0.2 \mathrm{~mL} \mathrm{~min}^{-1}$, $\left.[\mathrm{CYN}]_{0}=25 \mu \mathrm{g} \mathrm{L}^{-1},\left[\mathrm{H}_{2} \mathrm{O}_{2}\right]_{0}=5 \mathrm{mg} \mathrm{L}^{-1}, \mathrm{~W}_{\mathrm{Fe} 3 \mathrm{O} 4}=14 \mathrm{~g}, \mathrm{pH}_{0}=5, \mathrm{~T}=25^{\circ} \mathrm{C}\right)$.

\section{Materials and Methods}

\subsection{Chemicals}

CYN (>99\%) was supplied by Laboratorio CIFGA S.A. (Lugo, Spain). The chemical structure of this cyanotoxin, together with its chemical weight, is provided in Table 2 . Nitric acid (65\%), hydrogen peroxide solution $(30 \% \mathrm{wt})$, methanol (HPLC grade) and trifluoroacetic acid $(\geq 99 \%)$ were obtained from Sigma-Aldrich (Darmstadt, Germany). Natural magnetite powder (ref. 50121500) and natural magnetite granules with a nominal particle size between 3 and $8 \mathrm{~mm}$ (ref. 0029882796573) were provided by Marphil S.L. (Madrid, Spain) and Inoxia (Dunsfold, United Kingdom), respectively. Unless otherwise indicated, oxidation experiments were carried out in deionized water.

Table 2. Nomenclature, molecular weight, structural formula and CWPO reaction stoichiometry of CYN.

\begin{tabular}{ccccc}
\hline Name & Abbreviation & Molecular Weight & Reaction \\
\hline Cylindrospermopsin & $\mathrm{CYN}$ & $415.4 \mathrm{~g} \mathrm{~mol}^{-1}$ & Structural Formula & \\
\hline
\end{tabular}

\subsection{Catalyst Characterization}

The powdered $\mathrm{Fe}_{3} \mathrm{O}_{4}$ catalyst was fully characterized in previous work [21]. Briefly, the iron content was close to the theoretical one for pure magnetite (73 wt.\%). In fact, the XRD pattern revealed that the only phase present in the solid was crystalline magnetite and the material exhibited strong magnetic properties $\left(\mathrm{M}_{\mathrm{S}}=77.9 \mathrm{emu} \mathrm{g}^{-1}\right)$. Consistent with this kind of natural material [22,23], 
the specific surface area was relatively low $\left(\sim 7 \mathrm{~m}^{2} \mathrm{~g}^{-1}\right)$. The point of zero charge $\left(\mathrm{pH}_{\mathrm{PZC}}\right)$ was 7.8 . The particles showed a spherical shape with a mean diameter of $0.2 \mu \mathrm{m}$.

In this work, $\mathrm{SEM}$ images of both $\mathrm{Fe}_{3} \mathrm{O}_{4}$ powder and granules (ground and sieved in different size ranges) were obtained using a JSM 6335F microscope (JEOL Ltd., Tokio, Japan). The particle size distribution was measured by a laser diffraction particle size analyzer (Mastersizer 3000, Malvern Instruments Ltd. Malvern, UK). Elemental analyses of the catalysts were carried out in a LECO CHNS-932 Elemental Analyzer (LECO Corporation, Michigan, USA). Their specific surface area was characterized from nitrogen adsorption-desorption isotherms at $-196{ }^{\circ} \mathrm{C}$ (Micromeritics Tristar 3020 apparatus, Micromeritics Instrument Corporation, Norcross, GA, USA).

\subsection{CWPO Experiments}

CWPO trials were performed in a fixed-bed reactor made of a glass tube (18 $\mathrm{mm}$ i.d., $115 \mathrm{~mm}$ length), operating at ambient temperature and pressure and circumneutral $\mathrm{pH}\left(\mathrm{pH}_{0}=5\right)$. The experimental set-up used is shown in Figure 8. The catalyst powder $\left(\mathrm{Fe}_{3} \mathrm{O}_{4}, 0.2 \mu \mathrm{m}\right)$ was packed between two layers of magnetite granules. The bottom layer $\left(\mathrm{Fe}_{3} \mathrm{O}_{4}, 2.5 \mathrm{~g}, 250-500 \mu \mathrm{m}\right)$ was used to achieve a better distribution of the aqueous solution in the catalytic bed. The top layer $\left(\mathrm{Fe}_{3} \mathrm{O}_{4}, 6 \mathrm{~g}, 500-1000 \mu \mathrm{m}\right)$ was placed to avoid the possible loss of the fine catalyst particles, taking advantage of their magnetic properties. These three layers were placed above glassy beads $(2-3 \mathrm{~mm})$ and a fine layer of glass wool. The SEM images of the magnetite powder and granules, together with their particle size distribution, are provided in Figure 7. The mixture of $\mathrm{CYN}$ and $\mathrm{H}_{2} \mathrm{O}_{2}$ at the desired concentrations was transferred to the reactor in an up-flow direction using a peristaltic pump.

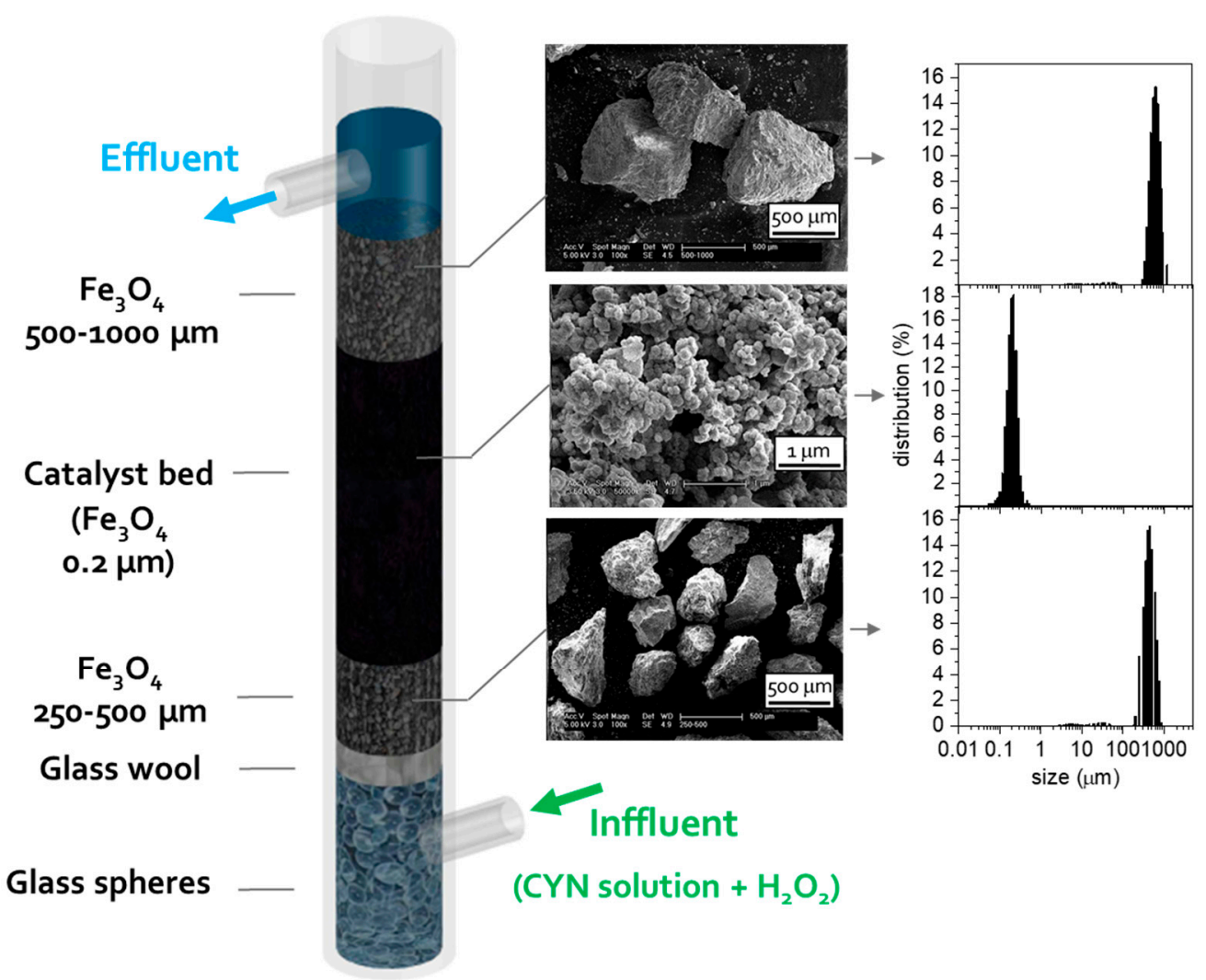

Figure 8. Scheme of the fixed-bed reactor used in the CWPO experiments, including SEM images and the particle size distribution of the $\mathrm{Fe}_{3} \mathrm{O}_{4}$ particles. 
Cyanotoxin conversion was the main parameter used to evaluate the activity of the catalyst, whereas dissolved iron concentration was also followed to assess its stability. CYN conversion was calculated according to the following equation:

$$
X_{C Y N}=\frac{C_{C Y N, 0}-C_{C Y N, t}}{C_{C Y N, 0}} \times 100(\%)
$$

where $C_{C Y N, 0}\left(\mu \mathrm{g} \mathrm{L}^{-1}\right)$ and $C_{C Y N, t}\left(\mu \mathrm{g} \mathrm{L}^{-1}\right)$ are the concentrations of $C Y N$ in the inlet and outlet solutions, respectively.

The experimental data obtained in the heterogeneous Fenton oxidation of CYN were described by an apparent pseudo-first order kinetic equation with regard to CYN, considering that the process takes place under kinetic control and the concentrations of the catalyst and $\mathrm{H}_{2} \mathrm{O}_{2}$ are kept constant throughout the experiments, as follows:

$$
\frac{W}{Q \cdot C_{C Y N, 0}}=\int_{0}^{X_{C Y N}} \frac{d X_{C Y N}}{k \cdot C_{C Y N, 0} \cdot\left(1-X_{C Y N}\right)}
$$

where $W$ is the magnetite load $(\mathrm{g}), Q$ is the feed flow rate $\left(\mathrm{mL} \mathrm{min}^{-1}\right), C_{C Y N, 0}$ is the initial concentration of $C Y N\left(\mu \mathrm{L} \mathrm{L}^{-1}\right.$ ), $X_{C Y N}$ is the conversion of $C Y N$ (from 0 to 1 ) and $k$ is the apparent pseudo-first order rate constant $\left(\mathrm{mL} \mathrm{g}_{\mathrm{cat}}{ }^{-1} \mathrm{~min}^{-1}\right)$. The values of $X_{C Y N}$ used to calculate $k$ were those achieved once a steady state was reached, i.e., when the conversion remained constant in the reaction effluent.

The performance of the catalytic bed was evaluated by systematically changing the main variables of the system. The effect of the catalyst bed load $\left(\mathrm{W}_{\mathrm{Fe} 3 \mathrm{O} 4}\right)(8-14 \mathrm{~g})$, the feed flow rate (0.1-0.25 mL min $\left.{ }^{-1}\right), \mathrm{H}_{2} \mathrm{O}_{2}$ dose (0.5-8 $\left.\mathrm{mg} \mathrm{L}^{-1}\right)$ and the initial CYN concentration (25-100 $\mu \mathrm{g} \mathrm{L}^{-1}$ ) were investigated. The stability of the catalytic bed was also studied in a long-term continuous experiment (60 h). Finally, the impact of the water matrix's composition was assessed using real aqueous samples (river and pond water). All the experiments were carried out in triplicate and the standard deviation was below $5 \%$.

\subsection{Analytical Methods}

CWPO experiments were followed by withdrawing samples every $30 \mathrm{~min}$ from the treated effluent. They were immediately analyzed by a high-performance liquid chromatograph equipped with a diode array detector (HPLC-UV, Shimadzu Prominence-i LC-2030C LT, SPD-M30A, Shimadzu Corporation, Kioto, Japan). A solution of $2.5 \%$ methanol and $0.1 \%$ trifluoroacetic acid in water $(v / v)$ was used as the mobile phase; an Eclipse Plus C18 column (Agilent, $150 \times 46 \mathrm{~mm}, 5 \mu \mathrm{m}$ ) was used as the stationary phase. The mobile phase flow rate was fixed at $0.8 \mathrm{~mL} \mathrm{~min}^{-1}$ and the temperature of the column at $35^{\circ} \mathrm{C}$. CYN quantification was carried out at $261 \mathrm{~nm}$.

Dissolved iron and $\mathrm{H}_{2} \mathrm{O}_{2}$ concentrations were determined by the $o$-phenantroline [24] and titanium sulfate [25] methods, respectively. A Cary 60 UV-VIS spectrophotometer (Agilent Technologies, Santa Clara, CA, USA) was used in both cases. Real water samples taken from a river and a pond (both in the region of Madrid) were analyzed by a total organic carbon (TOC) analyzer (Shimadzu TOC $\mathrm{V}_{\mathrm{SCH}}$, Kioto, Japan).

\section{Conclusions}

The fixed-bed reactor composed of magnetite powder and granules developed in this work has proven to be a promising approach for the removal of cyanotoxins from water. Under optimized conditions (flow rate $=0.2 \mathrm{~mL} \mathrm{~min}^{-1},\left[\mathrm{H}_{2} \mathrm{O}_{2}\right]_{0}=5 \mathrm{mg} \mathrm{L}^{-1}, \mathrm{~W}_{\mathrm{Fe} 3 \mathrm{O} 4}=14 \mathrm{~g}, \mathrm{pH}_{0}=5, \mathrm{~T}=25^{\circ} \mathrm{C}$ ), up to $80 \%$ CYN conversion was reached. Remarkably, the removal of the cyanotoxin was not affected by its initial concentration, which is crucial, considering the seasonal appearance of blooms and their successive stages. Consistent with this fact, the kinetics of the process were successfully described by a pseudo-first order kinetic equation. Notably, the catalytic system showed high stability in a long-term continuous 
application (60 h on stream) and was also highly effective when real environmental samples (pond and river water) were used as aqueous matrices. The catalyst showed negligible iron leaching $(<0.2 \mathrm{wt} . \%)$, maintaining its properties unchanged after the process. Furthermore, the magnetite granule layer at the top of the magnetite powder catalyst avoided the loss of catalytic material, confirming the suitability of the system for practical implementation.

Author Contributions: Conceptualization, M.M. and Z.M.d.P.; methodology, J.N.-S. and D.O.; formal analysis, M.M., Z.M.d.P., J.N.-S. and D.O.; investigation, M.M., Z.M.d.P., J.N.-S. and D.O.; data curation, J.N.-S. and D.O.; writing—original draft preparation, M.M.; writing—review and editing, J.N.-S., D.O., Z.M.d.P., S.C., A.Q. and J.A.C.; supervision, M.M. and Z.M.d.P.; project administration, J.A.C.; funding acquisition, A.Q. and J.A.C. All authors have read and agreed to the published version of the manuscript.

Funding: This research has been supported by the CYTED Ibero-American Science and Technology Program for Development (CYTED-2019) through the project TALGENTOX and by Spanish Ministry for Science and Innovation (MICINN) through the project PCI2020-112013. M. Munoz thanks the Spanish MICINN for the Ramón y Cajal postdoctoral contract (RYC-2016-20648). D. Ortiz thanks the Spanish Ministry of Education and Professional Training (MEFP) for the FPU predoctoral grant (FPU19/04816). J. Nieto-Sandoval thanks the Spanish MICINN for the FPI predoctoral grant (BES-2017-081346).

Conflicts of Interest: The authors declare no conflict of interest.

\section{References}

1. Pantelić, D.; Svirčev, Z.; Simeunović, J.; Vidović, M.; Trajković, I. Cyanotoxins: Characteristics, production and degradation routes in drinking water treatment with reference to the situation in Serbia. Chemosphere 2013, 91, 421-441. [CrossRef]

2. O'neil, J.; Davis, T.; Burford, M.; Gobler, C. The rise of harmful cyanobacteria blooms: The potential roles of eutrophication and climate change. Harmful Algae 2012, 14, 313-334. [CrossRef]

3. Paerl, H.W.; Paul, V.J. Climate change: Links to global expansion of harmful cyanobacteria. Water Res. 2012, 46, 1349-1363. [CrossRef] [PubMed]

4. He, X.; Liu, Y.; Conklin, A.; Westrick, J.; Weavers, L.K.; Dionysiou, D.D.; Lenhart, J.J; Mouser, P.J.; Szlag, D.; Walker, H.W. Toxic cyanobacteria and drinking water: Impacts, detection, and treatment. Harmful Algae 2016, 54, 174-193. [CrossRef] [PubMed]

5. Kumar, P.; Hegde, K.; Brar, S.K.; Cledon, M.; Kermanshahi pour, A. Physico-chemical treatment for the degradation of cyanotoxins with emphasis on drinking water treatment-How far have we come? J. Environ. Chem. Eng. 2018, 6, 5369-5388. [CrossRef]

6. Westrick, J.A.; Szlag, D.C.; Southwell, B.J.; Sinclair, J. A review of cyanobacteria and cyanotoxins removal/inactivation in drinking water treatment. Anal. Bioanal. Chem. 2010, 397, 1705-1714. [CrossRef]

7. Munoz, M.; Nieto-Sandoval, J.; Cirés, S.; de Pedro, Z.M.; Quesada, A.; Casas, J.A. Degradation of widespread cyanotoxins with high impact in drinking water (microcystins, cylindrospermopsin, anatoxin-a and saxitoxin) by CWPO. Water Res. 2019, 163, 114853. [CrossRef] [PubMed]

8. Andreozzi, R.; Caprio, V.; Insola, A.; Marotta, R. Advanced oxidation processes (AOP) for water purification and recovery. Catal. Today 1999, 53, 51-59. [CrossRef]

9. Munoz, M.; Cirés, S.; de Pedro, Z.M.; Colina, J.A.; Velásquez-Figueroa, Y.; Carmona-Jiménez, J.; Caro-Borrero, A.; Salazar, A.; Santa María Fuster, M.C.; Contreras, D.; et al. Overview of toxic cyanobacteria and cyanotoxins in Ibero-American freshwaters: Challenges for risk management and opportunities for removal by advanced technologies. Sci. Total Environ. 2020. under review. [CrossRef]

10. Wormer, L.; Cirés, S.; Carrasco, D.; Quesada, A. Cylindrospermopsin is not degraded by co-occurring natural bacterial communities during a 40-day study. Harmful Algae 2008, 7, 206-213. [CrossRef]

11. Armah, A.; Hiskia, A.; Kaloudis, T.; Chernoff, N.; Hill, D.; Antoniou, M.G.; He, X.; Loftin, K.; O'Shea, K.; Zhao, C.; et al. A review on cylindrospermopsin: The global occurrence, detection, toxicity and degradation of a potent cyanotoxin. Environ. Sci. Process. Impacts 2013, 15, 1979-2003.

12. He, X.; de la Cruz, A.A.; O'Shea, K.E.; Dionysiou, D.D. Kinetics and mechanisms of cylindrospermopsin destruction by sulfate radical-based advanced oxidation processes. Water Res. 2014, 63, 168-178. [CrossRef] [PubMed]

13. Pignatello, J.J.; Oliveros, E.; MacKay, A. Advanced oxidation processes for organic contaminant destruction based on the Fenton reaction and related chemistry. Crit. Rev. Environ. Sci. Technol. 2006, 36, 1-84. [CrossRef] 
14. Sievers, M. Advanced oxidation processes. Treatise Water Sci. 2011, 4, 377-408.

15. Munoz, M.; Pliego, G.; de Pedro, Z.M.; Casas, J.A.; Rodriguez, J.J. Application of intensified Fenton oxidation to the treatment of sawmill wastewater. Chemosphere 2014, 109, 34-41. [CrossRef] [PubMed]

16. Pera-Titus, M.; García-Molina, V.; Baños, M.A.; Giméneza, J.; Esplugas, S. Degradation of chlorophenols by means of advanced oxidation processes: A general review. Appl. Catal. B 2004, 47, 219-256. [CrossRef]

17. Carmichael, W.W. The toxins of cyanobacteria. Sci. Am. 1994, 270, 78-86. [CrossRef]

18. Li, X.; Chen, S.; Zeng, J.; Chabi, K.; Song, W.; Xian, X.; Yu, X. Impact of chlorination on cell activation, toxin release and degradation of cyanobacteria of development and maintenance stage. Chem. Eng. J. 2020, 397, 125378. [CrossRef]

19. Tang, X.; Krausfeldt, L.E.; Shao, K.; LeCleir, G.R.; Stough, J.M.; Gao, G.; Boyer, G.L.; Zhang, Y.; Paerl, H.W.; Qin, B. Seasonal gene expression and the ecophysiological implications of toxic Microcystis aeruginosa blooms in Lake Taihu. Environ. Sci. Technol. 2018, 52, 11049-11059. [CrossRef]

20. Munoz, M.; Conde, J.; de Pedro, Z.M.; Casas, J.A. Antibiotics abatement in synthetic and real aqueous matrices by $\mathrm{H}_{2} \mathrm{O}_{2} /$ natural magnetite. Catal. Today 2018, 313, 142-147. [CrossRef]

21. Serrano, E.; Munoz, M.; de Pedro, Z.M.; Casas, J.A. Efficient removal of the pharmaceutical pollutants included in the EU Watch List (Decision 2015/495) by modified magnetite/ $\mathrm{H}_{2} \mathrm{O}_{2}$. Chem. Eng. J. 2018, 376, 120265. [CrossRef]

22. Costa, R.C.C.; Lelis, M.F.F.; Oliveira, L.C.A.; Fabris, J.D.; Ardisson, J.D.; Rios, R.R.V.A.; Silva, C.N.; Lago, R.M. Novel active heterogeneous Fenton system based on $\mathrm{Fe}_{3}-\mathrm{xM}_{\mathrm{x}} \mathrm{O}_{4}(\mathrm{Fe}, \mathrm{Co}, \mathrm{Mn}, \mathrm{Ni})$ : The role of $\mathrm{M}^{2+}$ species on the reactivity towards $\mathrm{H}_{2} \mathrm{O}_{2}$ reactions. J. Hazard. Mater. 2006, 129, 171-178. [CrossRef] [PubMed]

23. He, H.; Zhong, Y.; Liang, X.; Tan, W.; Zhu, J.; Wang, C.Y. Natural magnetite: An efficient catalyst for the degradation of organic contaminant. Sci. Rep. 2015, 5, 1-10. [CrossRef]

24. Sandell, E.B. Colorimetric Determination of Traces of Metals; Interscience Pubs.: New York, NY, USA, 1959.

25. Eisenberg, G.M. Colorimetric determination of hydrogen peroxide. Ind. Eng. Chem. Res. 1943, 15, 327-328. [CrossRef]

Publisher's Note: MDPI stays neutral with regard to jurisdictional claims in published maps and institutional affiliations.

(C) 2020 by the authors. Licensee MDPI, Basel, Switzerland. This article is an open access article distributed under the terms and conditions of the Creative Commons Attribution (CC BY) license (http://creativecommons.org/licenses/by/4.0/). 